\title{
Recycling disposable bamboo chopstick waste as a renewable energy resource: Case study in Khon Kaen University, Thailand
}

\author{
Supin Jodnok ${ }^{1}$, Pairaya Choeisai ${ }^{1,2,3^{*}}$ (D), Chaiyaput Kruehong ${ }^{4}$ and Krit Choeisai ${ }^{5}$
}

\begin{abstract}
This study focused on elucidating disposable bamboo chopstick (DBC) waste generation rate and identifying the appropriate carbonization temperature for recycling DBC waste as a renewable energy resource. A survey was conducted within the study area of Khon Kaen University (KKU). Of the student population of approximately 40,000, the questionnaire was completed by 470 students. The survey revealed a bamboo chopstick utilization rate equivalent to 0.46 pairs person ${ }^{-1} \mathrm{~d}^{-1}$. A carbonization process wit 1-h was carried out at 650 and at $900^{\circ} \mathrm{C}$ to compare the quality of charcoal recycled from DBC (DBC charcoal). The DBC charcoal prepared at $650^{\circ} \mathrm{C}$ was of a higher quality for use as fuel compared to $900^{\circ} \mathrm{C}$ prepared DBC charcoal; with 5.3 times higher BET surface area $\left(62 \times 10^{3} \mathrm{~m}^{2} \mathrm{~kg}^{-1}\right), 5 \%$ higher thermal efficiency $(31 \%), 15$ times higher hydrogen $(\mathrm{H})$ content $(1.9 \%$ of total mass content), and $1.0 \mathrm{MJ} \mathrm{kg}^{-1}$ higher heating values by bombs calorimeter $\left(32.8 \mathrm{MJ} \mathrm{kg}^{-1}\right)$. The utilization of DBC charcoal as the biomass fuel in gasification for electricity generation could produce $0.0395 \%$ of KKU consumption energy which was estimated to reduce $\mathrm{CO}_{2}$ emission by $12.9 \mathrm{t} \mathrm{CO}_{2} \mathrm{yr}^{-1}$ as well as waste generation at $43.7 \mathrm{tyr}^{-1}$ or 0.399\% around KKU area.
\end{abstract}

Keywords: Recycling, Alternative fuel, Disposable bamboo chopsticks, Charcoal

\section{Introduction}

Due to their convenience and cheapness, disposable chopsticks made of bamboo, or disposable bamboo chopsticks (DBCs), are widely used in many street-food stalls, deli stores, and restaurants in East and Southeast Asian countries, including Thailand. China, the country from which chopsticks originated and the country most associated with their use, has reported a DBC usage rate of about 80 billion pairs annually, requiring the deforesting of 20 million 20 -year-old trees $\mathrm{yr}^{-1}$ [1].

\footnotetext{
* Correspondence: pairaya@yahoo.com

${ }^{1}$ Department of Environmental Engineering, Khon Kaen University, Khon Kaen 40002, Thailand

${ }^{2}$ Research Center for Environmental and Hazardous Substance Management, Khon Kaen University, Khon Kaen 40002, Thailand

Full list of author information is available at the end of the article
}

No data could be found on Thailand's DBC consumption and production quantities. However, it is clear that apart from the deforestation problem in Thailand, DBCs have become a significant problem for municipal waste collection, since as soon as they are discarded with other garbage into the plastic garbage bag, they punch holes into the bag, causing spillage.

As a processed product of bamboo, DBCs have high potential as biomass and are traditionally used in charcoal production in China as a renewable energy resource [2]. The charcoal production process occurs through carbonization and is conducted in a kiln under limited oxygen conditions. Carbonization requires kiln temperature of $300^{\circ} \mathrm{C}$ or higher: the higher the temperature, the higher the fixed carbon content. Charcoal is classified into 3 ranges of fixed carbon content:

(c) The Author(s). 2021 Open Access This article is licensed under a Creative Commons Attribution 4.0 International License, which permits use, sharing, adaptation, distribution and reproduction in any medium or format, as long as you give appropriate credit to the original author(s) and the source, provide a link to the Creative Commons licence, and indicate if changes were made. The images or other third party material in this article are included in the article's Creative Commons licence, unless indicated otherwise in a credit line to the material. If material is not included in the article's Creative Commons licence and your intended use is not permitted by statutory regulation or exceeds the permitted use, you will need to obtain permission directly from the copyright holder. To view a copy of this licence, visit http://creativecommons.org/licenses/by/4.0/. 
low, high, and tar-free, which are differentiated according to their kiln temperature ranges: 300 to 400,400 to $500{ }^{\circ} \mathrm{C}$, and higher than $500{ }^{\circ} \mathrm{C}$, respectively [3].

To optimize the carbonization process, fixed carbon content should be maximized while minimizing hydrocarbon content, i.e., volatile matter content [4]. Mingjie [3] studied the characteristics of bamboo charcoal made at temperatures ranging from 300 to $1000^{\circ} \mathrm{C}$ at every $100^{\circ} \mathrm{C}$ difference. The results showed that to derive fixed carbon charcoal at levels higher than $80 \%$, the kiln temperature needed to be above $500^{\circ} \mathrm{C}$. Meanwhile, kiln temperatures of $1000^{\circ} \mathrm{C}$ resulted in charcoal with fixed carbon content of up to $93 \%$.

To solve the environmental and trash management issues caused by DBC use in Thailand within the boundary of study around the Khon Kaen University (KKU) area, this research investigated $\mathrm{DBC}$ waste recycling wherein DBCs were used to make biomass charcoal for use as biomass fuel for generation of electricity by novel technology of gasification process. Due to gasification process needing a small biomass fuel without or with a low volatile organic matter content, making biomass fuel in the form of charcoal from DBC waste was originally proposed. For these reasons, this study focused on recycling DBCs to create tar-free charcoal. The physical and chemical characteristics of DBCs were differentiated by the charcoal made at 2 different temperatures, 650 and $900{ }^{\circ} \mathrm{C}$, while carbonization time was fixed to $1 \mathrm{~h}$. The temperature $650^{\circ} \mathrm{C}$ was selected to study as the low range temperature for making tar-free charcoal due to the removal of volatile organic matters at temperatures higher than $600^{\circ} \mathrm{C}$ as mentioned above [5]. While temperature $900{ }^{\circ} \mathrm{C}$ was selected to study as a high range temperature due to the limitation of kiln temperature for carbonization. The temperature range between these two study temperatures was not observed as the trend could be referred to in the literature mentioned above. A survey was also conducted to quantify $\mathrm{DBC}$ waste generation for estimation of electricity generation and reduction of $\mathrm{CO}_{2}$ emission in the study area and determine the expected amount of $\mathrm{DBC}$ recycling if trends in the study sample are extrapolated to the KKU community.

\section{Materials and methods}

\section{The DBC used in this study}

Used DBCs were collected from restaurants around $\mathrm{KKU}$, washed with tap water, and sun dried for 1 day before undergoing the carbonization process. The DBCs had a diameter of $4.8 \times 10^{-3}-5.0 \times 10^{-3} \mathrm{~m}$ and length of $2 \times 10^{-1}-2.2 \times 10^{-1} \mathrm{~m}$. The washed and dried DBC weighed $3.25 \times 10^{-3} \mathrm{~kg}$ piece $^{-1}$ (when weighed individually rather than in pairs).

\section{Kiln and carbonization process}

A gas ceramic kiln was used for the carbonization process. An amount of $20 \mathrm{~kg}$ per batch of prepared DBC were packed in a kiln and burned. The kiln temperature was increased to the test temperature and then the $\mathrm{DBC}$ were burned at the test temperature for $1 \mathrm{~h}$. Two test temperatures, 650 and $900{ }^{\circ} \mathrm{C}$, were studied. The carbonization process applied to the $\mathrm{DBC}$ is shown in Fig. 1.

\section{Physical and chemical characteristics of DBC and DBC charcoal analysis \\ Proximate analysis}

The proximate analysis consisted of an analysis of moisture content, volatile matter, fixed carbon, and ash content according to ASTM standard methods (ASTM D1762-84, ASTM D5832-98).

\section{Ultimate analysis}

The ultimate analysis was used to determine the elemental composition of the biomass fuels. The elements carbon $(\mathrm{C})$, hydrogen $(\mathrm{H})$, nitrogen $(\mathrm{N})$, and sulfur $(\mathrm{S})$ were analyzed using a CHN-S analyzer (LECO, VTF 900).

\section{Calorific value $\left(H_{f}\right)$}

The fuel's calorific value was determined using a Bomb Calorimeter (LECO, AC-300), as well as by calculation using Dulong's formula, described in Eq. (1).

$$
\begin{aligned}
\mathrm{H}_{\mathrm{f}}= & 33.586 \mathrm{C}+141.924 \mathrm{H} \\
& +12.908 \mathrm{~S}-15.327 \mathrm{O}-3.538 \mathrm{O}_{2},\left[\mathrm{MJ} \mathrm{kg}^{-1}\right]
\end{aligned}
$$

where:

$$
\begin{aligned}
\mathrm{C} & =\text { carbon }(w t \%), \mathrm{H}=\text { hydrogen }(w t \%), \mathrm{O} \\
& =\text { oxygen }(w t \%), \text { and } \mathrm{S}=\text { sulfur }(w t \%)
\end{aligned}
$$

\section{Thermal efficiency $(\eta)$}

Thermal efficiency, or heat utilization efficiency, was defined by the ratio of heat used for water evaporation to heat produced from burning the fuel. It was used to evaluate the amount of heat derived from burning the fuel versus the heat applied toward evaporating the water [6]. A cooking stove was used for this evaluation. The thermal efficiency of the samples was calculated using the standard water boiling test (WBT), described in Eq. (2).

$$
\eta=\frac{\mathrm{M}_{\mathrm{w}} \mathrm{C}_{\mathrm{p}}\left(\mathrm{T}_{\mathrm{b}}-\mathrm{T}_{0}\right)+\mathrm{M}_{\mathrm{c}} \mathrm{L}}{\mathrm{M}_{\mathrm{f}} \mathrm{H}_{\mathrm{f}}} \times 100
$$

where:

$M_{w}=$ mass of water $(\mathrm{kg}), \mathrm{C}_{\mathrm{p}}=$ specific heat of water $\left[\mathrm{MJ} \mathrm{kg}{ }^{-1}{ }^{\circ} \mathrm{C}^{-1}\right], \mathrm{T}_{\mathrm{b}}=$ boiling temperature of water $\left({ }^{\circ} \mathrm{C}\right)$, 

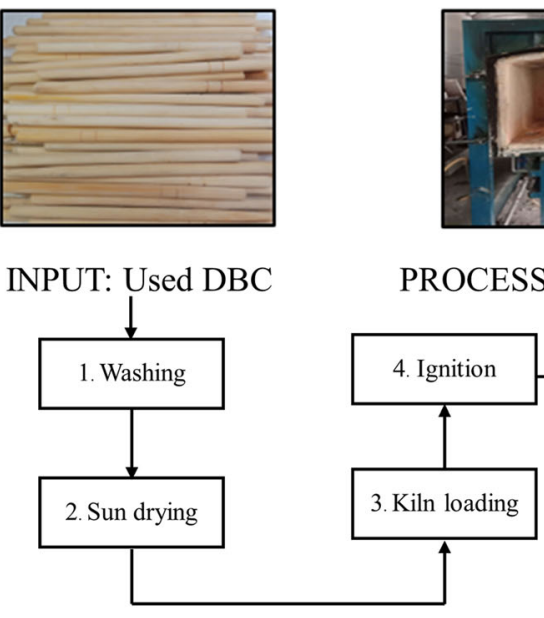

Fig. 1 The DBC carbonization process
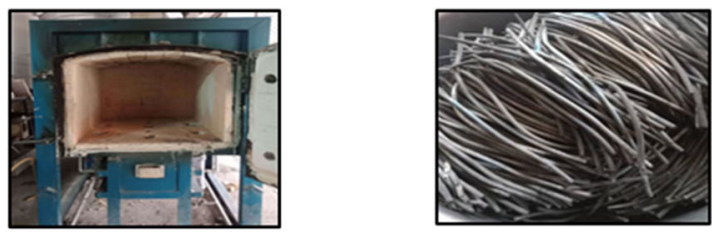

PROCESS: Carbonization

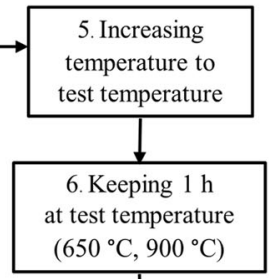

OUTPUT: DBC charcoal

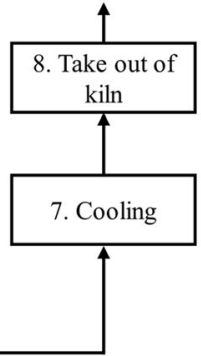

$\mathrm{T}_{0}=$ initial temperature of water $\left({ }^{\circ} \mathrm{C}\right), \mathrm{M}_{\mathrm{C}}=$ mass of evaporated water $(\mathrm{kg}), \mathrm{L}=$ latent heat of evaporation $(\mathrm{MJ}$ $\left.\mathrm{kg}^{-1}\right), \mathrm{M}_{\mathrm{f}}=$ mass of DBC or DBC charcoal $(\mathrm{kg})$, and $\mathrm{H}_{\mathrm{f}}=$ calorific value of $\mathrm{DBC}$ or $\mathrm{DBC}$ charcoal derived from analysis $\left(\mathrm{MJ} \mathrm{kg}^{-1}\right)$.

\section{Burn-off weight percentage}

The burn-off weight percentage was defined by the ratio of the DBC's weight after undergoing carbonization to its original weight when loaded into the kiln as raw material prior to carbonization [7]. The burn-off weight percentage was calculated using Eq. (3).

$$
\text { Burn-off weight percentage }=\frac{\mathrm{W}_{\mathrm{i}}-\mathrm{W}_{\mathrm{f}}}{\mathrm{W}_{\mathrm{i}}} \times 100
$$

where:

$\mathrm{W}_{\mathrm{i}}$ = the initial weight of the raw material (DBC at kiln loading) and $\mathrm{W}_{\mathrm{f}}=$ the final weight of the product ( $\mathrm{DBC}$ after carbonization process).

\section{Scanning electron microscopy (SEM) and image processing} Morphological changes of the DBCs and DBC charcoal samples were observed under SEM (LEO, 1450VP). SEM image processing was carried out with Visio Professional 2013 in order to estimate the samples' pore-size distribution. Pore size distribution data were used to calculate an estimated average pore size for each sample.

\section{Brunauer-Emmett-teller (BET) surface area analysis}

BET surface area analysis was performed using $\mathrm{N}_{2}$ adsorption-desorption equipment (Micrometrics, ASPS2460).
Assessment and estimation of DBC waste and DBC charcoal generation per capita

It can be assumed that DBC waste generation is equivalent to DBC consumption. Consumption of DBC per capita was assessed by distributing questionnaires to KKU students through Google Forms. The student population of KKU is approximately 40,000, and guidelines described by Krejcie and Morgan [8] were used to establish sample size for the study design. Based on Eq. (4) shown below, a sample size of 470 participants was calculated. DBC consumption for each day of the 7 days previous to completing the questionnaire was reported, as well as general information of participants (age range, gender, and education level). The data gathered through Google Forms were analyzed using STATA Version 14. Sample size was calculated using Eq. (4).

$$
n=\frac{x^{2} N p(1-p)}{e^{2}(N-1)+x^{2} p(1-p)}
$$

where:

$\mathrm{n}=$ required sample size, $\mathrm{x}^{2}=$ the table value of chisquare for 1 degree of freedom at the desired confidence level \% $\left(\mathrm{x}^{2}=3.841\right), \quad N=$ the population size, $p=$ the population proportion (assumed to be 0.50 since this would provide the maximum sample size), and $\mathrm{e}=$ the degree of accuracy expressed as a proportion $(e=0.05)$.

\section{Results and discussion}

\section{Physical characteristics}

The findings from the surface morphology study of DBC and $\mathrm{DBC}$ charcoal through photographic image and SEM analyses are shown in Fig. 2. Figure 2a1, b1, and c1 are the photographic images of the DBCs, DBC charcoal processed at $650{ }^{\circ} \mathrm{C}$ (hereinafter $650{ }^{\circ} \mathrm{C}$ DBC charcoal), 

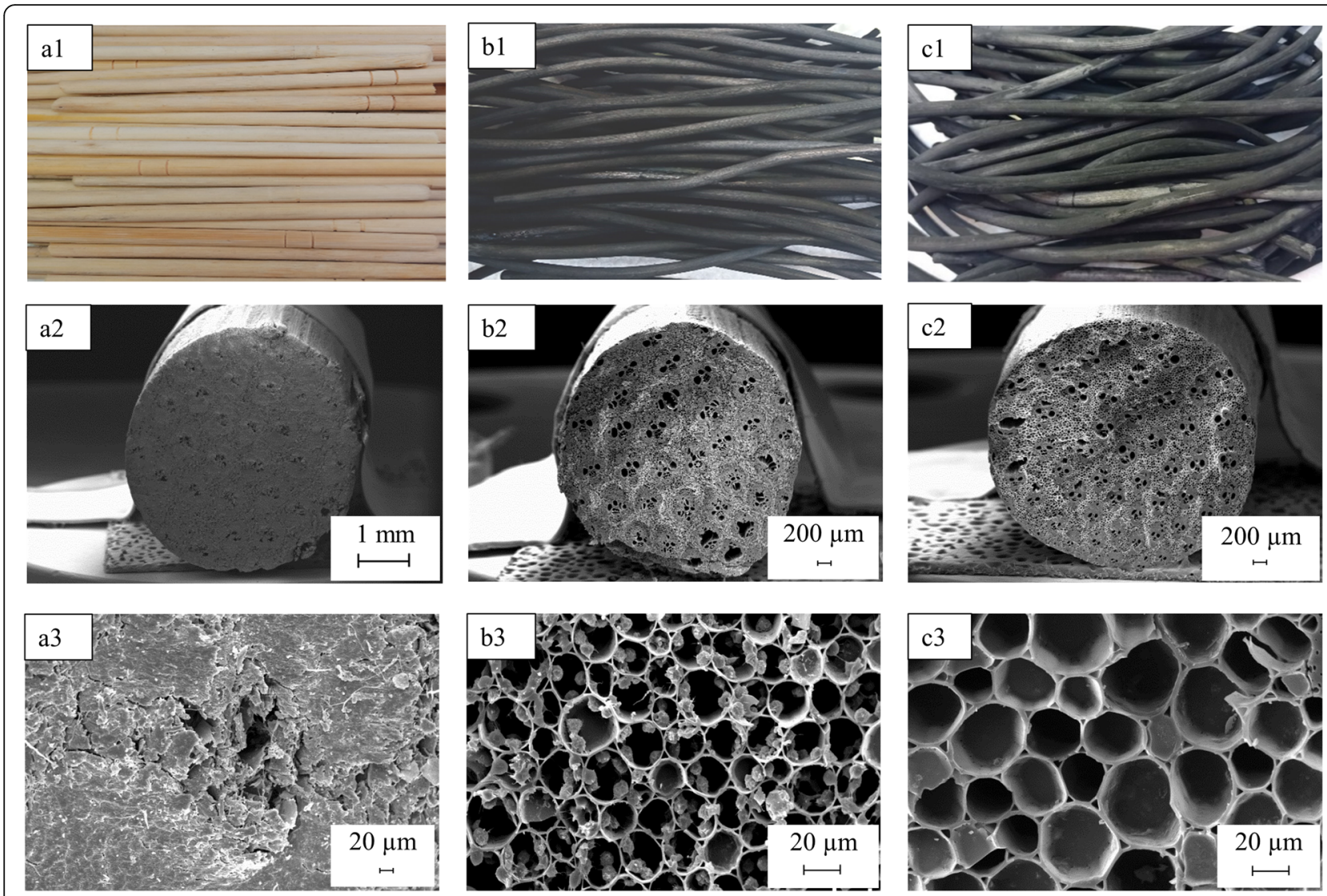

Fig. 2 Photographic images and SEM images of DBC and DBC charcoal: (a1) photograph of DBC; (a2 and a3) SEM of DBC; (b1) photograph of $650^{\circ} \mathrm{C}$ DBC charcoal; (b2 and c2) SEM of $650^{\circ} \mathrm{C}$ DBC charcoal; (c1) photograph of $900^{\circ} \mathrm{C}$ DBC charcoal; (c2 and c3) SEM of $900^{\circ} \mathrm{C}$ DBC charcoal

and $\mathrm{DBC}$ charcoal processed at $900{ }^{\circ} \mathrm{C}$ (hereinafter $900^{\circ} \mathrm{C}$ DBC charcoal). Cross-section images of $\mathrm{DBC}$, $650^{\circ} \mathrm{C}$ DBC charcoal, and $900^{\circ} \mathrm{C}$ DBC charcoal taken by SEM with low magnification power are presented in Fig. 2a2, b2, and c2, and with high magnification power in Fig. 2a3, b3, and c3. The latter elucidated that the DBC cross-section surface (Fig. 2a3) appeared to be a packed wooden mass, while the 650 and $900^{\circ} \mathrm{C}$ DBC charcoal cross-section images (Fig. 2b3, and c3) looked similar to straws tied or packed together. The 650 and $900^{\circ} \mathrm{C}$ DBC charcoal cross section images (Figs. 2b3, and c3) differed from each other in terms of the size and clarity of their pores. Small particles were attached to the pores that appeared in the $650^{\circ} \mathrm{C}$ DBC charcoal cross-section image; these were absent in the $900{ }^{\circ} \mathrm{C}$ DBC image. The pore size in the $900^{\circ} \mathrm{C}$ DBC charcoal appeared larger than that of the $650{ }^{\circ} \mathrm{C}$ DBC charcoal.

The SEM images in Fig. 2 (b3 and c3) were analyzed using image processing software in order to collect pore diameter size distribution data. The average pore diameter of the $650{ }^{\circ} \mathrm{C}$ DBC charcoal was $21.8 \mu \mathrm{m}$ based on a count of 70 pores. The average pore diameter of the $900{ }^{\circ} \mathrm{C}$ DBC charcoal was $32.6 \mu \mathrm{m}$ based on a count of
40 pores. These results confirmed that the pore diameter of the $900{ }^{\circ} \mathrm{C}$ DBC charcoal was 1.5 times larger than that of the $650{ }^{\circ} \mathrm{C} \mathrm{DBC}$ charcoal.

A comparison of the BET surface area along with the weight ratio changes in terms of weight percentage to burn-off weight percentage after carbonization for DBC at 650 and $900{ }^{\circ} \mathrm{C}$ relative to the weight of the original DBC material of DBC and DBC charcoal was carried out and is presented in Table 1 . It should be noted that the BET surface area of original DBC could not be determined due to blockage by the wood mass, as elucidated in Fig. 2a3. Therefore, the surface area of DBC was calculated using its outside surface area divided by its weight, resulting in a surface area of $0.0014 \mathrm{~m}^{2} \mathrm{~g}^{-1}$. The BET surface area of the $650{ }^{\circ} \mathrm{C} \mathrm{DBC}$ charcoal and $900{ }^{\circ} \mathrm{C}$ DBC charcoal was 62 and $12 \mathrm{~m}^{2} \mathrm{~g}^{-1}$, respectively. The BET surface area of the $650{ }^{\circ} \mathrm{C} \mathrm{DBC}$ charcoal was, therefore, 5.3 times larger than that of the $900^{\circ} \mathrm{C}$ DBC charcoal. Increasing the temperature above 650 to $900{ }^{\circ} \mathrm{C}$ enhanced the release of volatile matter, resulting in pores with larger diameters, as shown in Fig. 2. These surface area findings are consistent with previous research on charcoal making [3], which found that 
Table 1 Physical characteristics of the test samples

\begin{tabular}{|c|c|c|c|}
\hline Parameters & $\begin{array}{l}\text { Original } \\
\text { DBC }\end{array}$ & $650^{\circ} \mathrm{C}$ DBC charcoal & $900^{\circ} \mathrm{C}$ DBC charcoal \\
\hline \multicolumn{4}{|l|}{ Proximate analysis } \\
\hline Moisture content (\%wt) & 6.4 & 4.5 & 8.3 \\
\hline Volatile matter (\%wt) & 75.4 & 9.2 & 4.6 \\
\hline Fixed carbon (\%wt) & 15.7 & 80.4 & 79.5 \\
\hline Ash content (\%wt) & 2.5 & 5.9 & 7.7 \\
\hline \multicolumn{4}{|l|}{ Calorific value $\left(\mathrm{MJ} \mathrm{kg}^{-1}\right)$} \\
\hline By bomb calorimeter (B) & 17.7 & 32.8 & 31.9 \\
\hline By calculation using Dulong's formula (C) & 16.5 & 30.9 & 29.4 \\
\hline$\%$ Difference $=\frac{(B-C)}{B} \times 100$ & 6.6 & 6.1 & 7.6 \\
\hline Thermal efficiency (\%) & 17 & 31 & 26 \\
\hline Fuel consumption rate $\left(\mathrm{kg} \mathrm{h}^{-1}\right)$ & 0.79 & 0.29 & 0.31 \\
\hline BET surface area $\left(\mathrm{m}^{2} \mathrm{~g}^{-1}\right)$ & $N D^{a}$ & 62 & 12 \\
\hline Weight percentage (\% based on original DBC) & 100 & 27 & 25 \\
\hline Burn-off weight percentage (\% based on original DBC) & - & 73 & 75 \\
\hline
\end{tabular}

Remarks ${ }^{a}$ not detected

increasing the carbonization temperature from 300 to $700{ }^{\circ} \mathrm{C}$ caused an increase in surface area while further temperature increases caused the surface area to decrease.

The burn-off weight, or the weight lost during the carbonization process, serves as an index to determine the burn-off degree of the original material and to evaluate its suitability as a raw material. In the case of the washed and sun-dried DBC used in this study, after the carbonization process at $650^{\circ} \mathrm{C}$, the DBC lost $73 \%$ of its weight, and after the carbonization process at $900^{\circ} \mathrm{C}$, the DBC lost $75 \%$ of its weight, resulting in the 650 and $900{ }^{\circ} \mathrm{C}$ DBC charcoal having 27 and $25 \%$ of its original weight, respectively. The weight lost as a result of the carbonization process is presumed to be the weight of the moisture and volatile matter contained in DBC. Good quality charcoal should have a burn-off weight percentage between 72 and $75 \%$ [9].

The other physical characteristics of the test samples are also summarized in Table 1, with the test parameters of proximate analysis, calorific value, thermal efficiency and fuel consumption rate. Findings from the proximate analysis, including analyses of moisture content, volatile matter, fixed carbon, and ash content of the test samples, are shown. High-quality fuel must have high fixed carbon content and low amounts of volatile matter. Carbonization at temperatures of 650 and $900{ }^{\circ} \mathrm{C}$ increased the quality of the DBC as fuel, resulting in an increased fixed carbon content and lowered volatile matter content in both cases. Fixed carbon content was increased by almost the same amount in both cases, from $15.7 \%$ wt to 80.4 and $79.5 \%$ wt for $650^{\circ} \mathrm{C}$ DBC charcoal and $900^{\circ} \mathrm{C}$ DBC charcoal, respectively. The volatile matter content decreased from 75.4 to 9.2 and $4.6 \%$ wt for $650^{\circ} \mathrm{C}$ DBC charcoal and $900^{\circ} \mathrm{C}$ DBC charcoal, respectively. While the volatile matter content of the $650^{\circ} \mathrm{C}$ DBC charcoal was 2 times higher than that of the $900^{\circ} \mathrm{C}$ DBC charcoal, the difference did not significantly affect fuel quality since the value was lower than $10 \%$ in both cases. The lower the moisture content, the better its fuel properties will be. Moisture content is determined by oven drying a weighed sample of the charcoal. It is expressed as a percentage of the initial wet weight. If moisture content is high, igniting the fuel will be more difficult, and heat energy will be lost to the evaporation energy of the water content in the fuel. The moisture content of the $900{ }^{\circ} \mathrm{C}$ DBC charcoal was approximately 2 times higher than that of the $650^{\circ} \mathrm{C} \mathrm{DBC}$ charcoal and 1.3 times higher than that of the $\mathrm{DBC}$. Its higher moisture content was most likely due to its superior absorption properties, which would cause it to absorb water more easily from the air. Furthermore, the fact that the moisture content of the original DBC was less than that of $900{ }^{\circ} \mathrm{C}$ DBC charcoal can be backed up by literature. Absorption of moisture from the humidity of the air itself is rapid and there is, with time, a gain of moisture which even without any rain wetting can bring the moisture content increase to about 5-10\%. Quality specifications for charcoal usually limit the moisture content to around $5-15 \%$ of the gross weight of the charcoal [5]. The proximate results suggested that the $650^{\circ} \mathrm{C}$ DBC charcoal would be the best fuel among the test samples. Its fixed carbon content was similar to that of charcoal made at higher temperatures; its volatile matter content 
was higher but only to an insignificant degree; and it had lower moisture content and lower input energy demand for recycling via carbonization.

The calorific values of $\mathrm{DBC}$ and $\mathrm{DBC}$ charcoal were analyzed to estimate their potential for energy production. Two different methods, bomb calorimeter and Dulong's formula, were used with their findings shown Table 1. While bamboo wood's calorific value has been found to be approximately $16.9 \mathrm{MJ} \mathrm{kg}^{-1}$ [2], the calorific value of the $\mathrm{DBC}$ in this study was determined to be $17.1 \mathrm{MJ} \mathrm{kg}{ }^{-1}$ when analyzed with the bomb calorimeter and $16.5 \mathrm{MJ} \mathrm{kg}^{-1}$ when calculated using Dulong's formula. This shows that bamboo wood and DBC have very similar calorific values. The difference in calorific value when using the bomb calorimeter versus Dulong's formula was 6 to $8 \%$. A trend of calorific value variance in response to the carbonization process was observed with both analysis methods. The $650^{\circ} \mathrm{C}$ DBC charcoal showed the highest calorific value among the test samples. The bomb calorimeter showed the $650^{\circ} \mathrm{C} \mathrm{DBC}$ charcoal with a calorific value $85 \%$ higher than $\mathrm{DBC}$ and $3 \%$ higher than $900{ }^{\circ} \mathrm{C} \mathrm{DBC}$ charcoal. This was in line with the calculation results, according to which the $650{ }^{\circ} \mathrm{C}$ DBC charcoal had a calorific value $87 \%$ higher than $\mathrm{DBC}$ and $5 \%$ higher than $900^{\circ} \mathrm{C}$ DBC charcoal. The results in Table 1 imply that when recycling $\mathrm{DBC}$ for use as a renewable fuel such as charcoal, the carbonization temperature of $650^{\circ} \mathrm{C}$ is more efficient than $900^{\circ} \mathrm{C}$. A $650^{\circ} \mathrm{C}$ carbonization process could reduce transportation weight by up to $73 \%$ and increase calorific value by 1.9 times relative to using DBC directly as fuel without carbonization. Moreover, charcoal is more suitable for storage than $\mathrm{DBC}$, as $\mathrm{DBC}$ is prone to decomposition by insects or fungi.

Thermal efficiency measures the percentage of heat produced by the fuel that the heat device is able to transform into work energy. In this study, a cooking stove was set up as a heat device for testing, and the percentage of heat transfer achieved by each of the test samples was determined. Thermal efficiency was defined by the percentage of heat that was transferred from the chemical energy in the fuel to the task of boiling the water, as described by the WBT. The thermal efficiencies of the three test samples are shown in Table 1 . The thermal efficiency of the DBC was $17 \%$, while the $650^{\circ} \mathrm{C}$ DBC charcoal and $900^{\circ} \mathrm{C}$ DBC charcoal had thermal efficiency of 31 and $26 \%$, respectively. The fuel consumption rates of the $\mathrm{DBC}, 6500^{\circ} \mathrm{C} \mathrm{DBC}$ charcoal, and $900^{\circ} \mathrm{C}$ DBC charcoal were $0.79,0.29$, and $0.31 \mathrm{~kg} \mathrm{~h}^{-1}$, respectively. These results correlated with the calorific value findings, with the $650^{\circ} \mathrm{C}$ DBC charcoal having optimal performance as a source of renewable energy. The $650^{\circ} \mathrm{C}$ DBC charcoal had the lowest fuel consumption rate and the highest thermal efficiency.
The thermal efficiency tests were carried out in triplicate with the three types of test samples, each of the same weight and using the same cooking stove on the same day. Figure 3 shows the average flame temperature of the cooking stove versus combustion time during the thermal efficiency tests. The results showed that when using $650^{\circ} \mathrm{C} \mathrm{DBC}$ charcoal as fuel, the temperature reached $979{ }^{\circ} \mathrm{C}$, the highest temperature among the three types of fuel. The $650^{\circ} \mathrm{C} \mathrm{DBC}$ charcoal had the largest BET surface area and a specific physical structure, as the SEM images showed organic matter in its pores. This unique physical structure may explain the higher flame temperature of the cooking stove and the longer combustion duration time achieved in the thermal efficiency test. The organic matter in the fuel may have accelerated the combustion reaction. The reaction kinetics of the $\mathrm{DBC}$ and $650^{\circ} \mathrm{C}$ DBC charcoal were similar from the start of the combustion reaction until the flame reached its peak temperature. The reaction kinetics of the $650{ }^{\circ} \mathrm{C}$ DBC charcoal and $900{ }^{\circ} \mathrm{C}$ DBC charcoal showed similar trends as the flame temperature decreased after peaking, and the combustion duration of the two charcoals were very similar. It can be assumed that the similar tube-like structures of the two charcoals, or their porous structures, led to an increase in their surface areas and allowed oxygen in the air to flow through the fuel, thus increasing the combustion reaction time.

\section{Chemical characteristics}

Findings from chemical characteristics analysis results of the three test samples, with bituminous coal findings for comparison, are summarized in Table 2.

An ultimate analysis is an analysis of the chemical characteristics of a fuel in terms of the main elements in

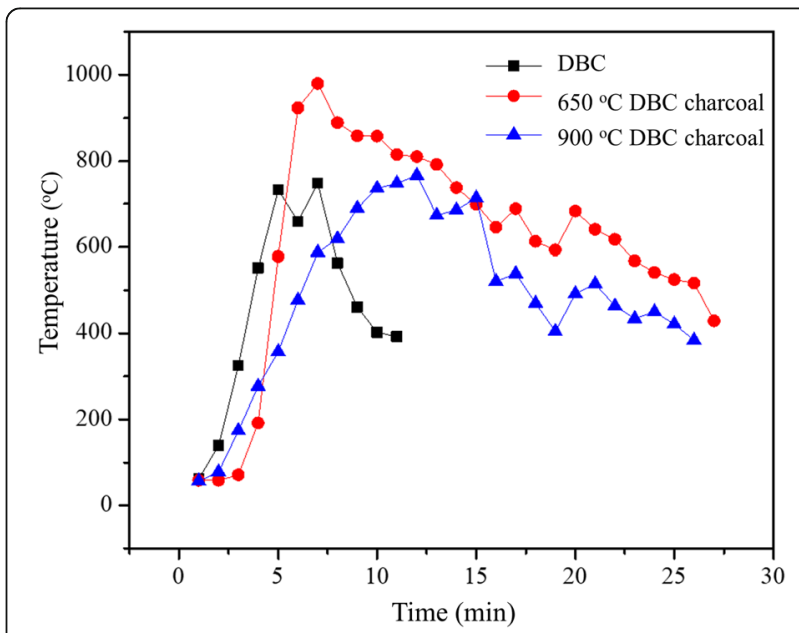

Fig. 3 Comparison of cooking stove's flame temperature versus combustion time during the thermal efficiency test with different test samples as fuel 
Table 2 Chemical characteristics of the test samples

\begin{tabular}{|c|c|c|c|c|}
\hline Parameters & $\begin{array}{l}\text { Original } \\
\text { DBC }\end{array}$ & $650^{\circ} \mathrm{C}$ DBC charcoal & $900^{\circ} \mathrm{C}$ DBC charcoal & Bituminous coal $^{\mathrm{T}}$ \\
\hline \multicolumn{5}{|l|}{ Ultimate analysis } \\
\hline Carbon (\%wt) & 45.3 & 87.9 & 90.8 & 71.3 \\
\hline Hydrogen (\%wt) & 6.6 & 1.9 & 0.1 & 5.5 \\
\hline Nitrogen (\%wt) & 0.3 & 0.7 & 0.8 & 1.4 \\
\hline Sulfur (\%wt) & 0.2 & 0.3 & 0.2 & 1.7 \\
\hline Oxygen (\%wt) & 47.6 & 9.3 & 8.1 & 8.7 \\
\hline \multicolumn{5}{|l|}{ Atomic molar ratio } \\
\hline $\mathrm{H} / \mathrm{C}$ & 1.76 & 0.26 & 0.02 & 0.93 \\
\hline $\mathrm{O} / \mathrm{C}$ & 0.79 & 0.08 & 0.07 & 0.09 \\
\hline $\mathrm{C} / \mathrm{N}$ & 189 & 155 & 128 & 59 \\
\hline Sulfur content to calorific value ratio $\left(\times 10^{-5} \mathrm{~kg} \mathrm{MJ}^{-1}\right)$ & 9.7 & 9.7 & 7.8 & 50 \\
\hline
\end{tabular}

weight percentages, including carbon, hydrogen, nitrogen, sulfur, and oxygen. In this study, the higher carbonization temperature led to a substantial increase in carbon and nitrogen contents. The carbon content of $650^{\circ} \mathrm{C}$ DBC charcoal and $900^{\circ} \mathrm{C}$ DBC charcoal were both approximately 2 times higher than that of the $\mathrm{DBC}$, at 87.9 and $90.8 \%$ wt, respectively. Conversely, a higher temperature during carbonization, led to lower hydrogen and oxygen contents. Sulfur was the only element that did not appear to correlate in content with carbonization temperature for any of the fuel samples. Sulfur is the element in fuel that causes air pollutant compounds such as sulfur dioxide $\left(\mathrm{SO}_{2}\right)$ or sulfur oxides $\left(\mathrm{SO}_{\mathrm{x}}\right)$ to form during the combustion reaction, and thus is considered the polluting factor of the fuel. The ultimate analysis found that the sulfur content of the DBC and DBC charcoal did not exceed $0.3 \mathrm{wt} \%$, whereas bituminous coal has been found to contain $1.7 \mathrm{wt} \%$ sulfur content.

As the data was not sufficient to conclude that DBC and DBC charcoal are cleaner than bituminous coal, the sulfur content to calorific value ratio was calculated by using the ultimate analysis data and calorific value calculated by Dulong's formula. The results are shown in Table 2. The results presented in Table 2 show that the $900{ }^{\circ} \mathrm{C}$ DBC charcoal was found to have the lowest sulfur content to calorific value and was lower than bituminous coal by $84 \%$. This shows that among the test samples, it would emit the least amount of sulfur into the air when used as fuel.

Atomic molar ratios obtained from the ultimate analysis are commonly used to determine the degree of aromaticity according to the hydrogen-to-carbon $(\mathrm{H} / \mathrm{C})$ ratio and polarity according to the oxygen-to-carbon $(\mathrm{O} /$ C) ratio and have been used for fuel characterization [11]. The weight percentages in the ultimate analysis were converted into molar fractions and then into the atomic ratios as presented in Table 2 . As the $\mathrm{H} / \mathrm{C}$ ratio increases, the aromaticity increases and the calorific value of the fuel decreases [4]. On the other hand, as the $\mathrm{O} / \mathrm{C}$ ratio increases, the polarity increases and the calorific value increases. Therefore, the $\mathrm{H} / \mathrm{C}$ and $\mathrm{O} / \mathrm{C}$ ratios must be considered together in order to classify and characterize the fuel. A Van Krevelen diagram was used to visualize and assess the samples' characteristics and likeness to common solid fuels in terms of the relationship between the atomic $\mathrm{H} / \mathrm{C}$ and $\mathrm{O} / \mathrm{C}$ ratios (Fig. 4).

In Fig. 4 , the $\mathrm{H} / \mathrm{C}$ and $\mathrm{O} / \mathrm{C}$ atomic molar ratios of the test samples are plotted on the graph in order to visualize their characteristics in relation to other common solid fuels. DBC is characterized in the low calorific value area along with biomass. Conversely, 650 and $900{ }^{\circ} \mathrm{C}$ DBC charcoals are characterized in the high calorific value area along with anthracite. Anthracite is characterized as a hard coal with high carbon content and submetallic luster and is known to ignite with difficulty [12].

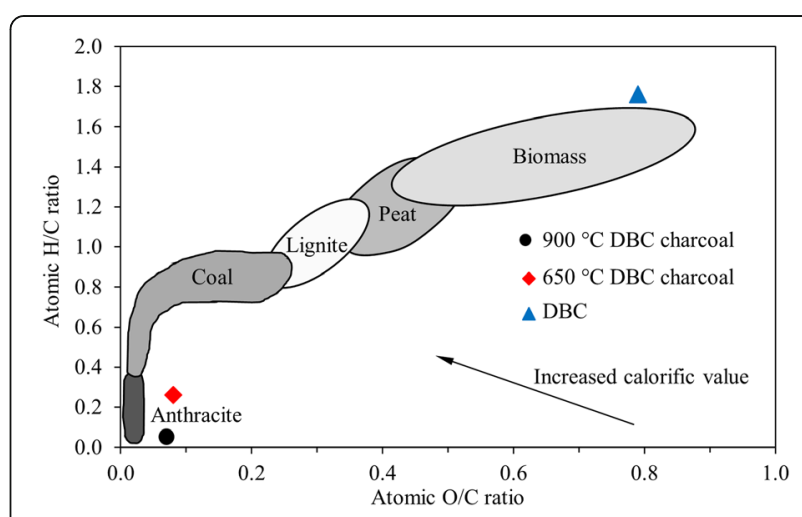

Fig. 4 The test samples plotted on a Van Krevelen plot to indicate their likeness to common solid fuels 
Table 3 Estimation of renewable energy production from DBC and $650^{\circ} \mathrm{C}$ DBC charcoal

\begin{tabular}{|c|c|c|c|c|}
\hline Type of fuel & Recycle weight $\left(\mathrm{kg} \mathrm{yr}^{-1}\right)$ & Calorific value $\left({\left.\mathrm{MJ} \mathrm{yr}^{-1}\right)}^{-1}\right.$ & Tonne of oil equivalent $\left(\mathrm{kt}_{\mathrm{yr}} \mathbf{r}^{-1}\right)$ & 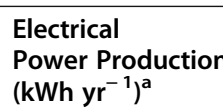 \\
\hline DBC & 43,654 & 773,110 & 0.01835 & 67,025 \\
\hline $650^{\circ} \mathrm{C}$ DBC charcoal & 11,787 & 387,070 & 0.00919 & 33,557 \\
\hline
\end{tabular}

${ }^{a}$ calculated using thermal efficiency for biomass gasification at $31 \%$ [13]

The DBC consumption rate and estimation of renewable energy production from DBC waste converted to charcoal at $650^{\circ} \mathrm{C}$

A survey was conducted with $470 \mathrm{KKU}$ students. Their general information (age range, gender, and education level) showed that the average, minimum, and maximum age of the sample was 20,18 , and $43 \mathrm{yr}$, respectively. Males accounted for $61.5 \%$ and females $38.5 \%$ of the sample. Undergraduate students accounted for $89.8 \%$, while $10.2 \%$ of the sample were graduate students. Only 14 students, or $2 \%$ of the total 470 students, had not used any DBC in the previous $7 \mathrm{~d}$.

The respondents reported on their frequency of DBC use for each day of the week previous to taking the survey in order that the average number of $\mathrm{DBC}$ used per person per day could be calculated. On each day, more than $35 \%$ of the student sample used DBC, and on average $40.9 \%$ of the students used DBC each day. The total number of DBC used by the students each day was summed and averages of the data were calculated. While some students used more than one pair of DBC in a day, on other days they did not use any. Finally, the average DBC use rate was 0.46 pairs person ${ }^{-1} \mathrm{~d}^{-1}$.

Accordingly, in order to average the weight of DBC that could be recycled around KKU. The average chopstick weight was $6.5 \mathrm{~g} \mathrm{pair}^{-1}$. With a population of approximately 40,000 people, an average chopstick weight of $119.6 \mathrm{~kg} \mathrm{~d}^{-1}$ could be recycled into $32.3 \mathrm{~kg}$ of $650{ }^{\circ} \mathrm{C}$ DBC charcoal per day. At a market charcoal price of approximately 25 baht $\mathrm{kg}^{-1}$ ( $1 \mathrm{USD}=31.4$ baht) converting DBC waste to charcoal could have a value of 294,740 baht $\mathrm{yr}^{-1}$ and produce $387,070 \mathrm{MJ} \mathrm{yr}^{-1}$ in energy. The estimation of electricity production rate using $650{ }^{\circ} \mathrm{C}$ DBC charcoal by gasification per year were calculated and summarized in Table 3 . The electricity consumption rate of KKU per year is approximately 85,056,600 kWh [14]. Then, the alternative electricity production rate using $650{ }^{\circ} \mathrm{C} \mathrm{DBC}$ charcoal per year was estimated at $0.0395 \%$ based on KKU consumption energy. However, this amount is a small fraction compared to total electricity usage, but the reduction of $\mathrm{CO}_{2}$ emission is necessary in this global warming situation. From the report of Thailand Power Development Plan 2018 [15], $\mathrm{CO}_{2}$ emission rate from electricity generation in year 2021 by Thailand Provincial Electricity Authority is supposed to be $0.384 \mathrm{~kg} \mathrm{CO} \mathrm{KWh}^{-1}$, and the electricity production using gasification technique [13] has negative $\mathrm{CO}_{2}$ emission. Consequently, recycling of $\mathrm{DBC}$ to $650{ }^{\circ} \mathrm{C} \mathrm{DBC}$ charcoal for use as biomass materials for electricity generation by gasification method could reduce $\mathrm{CO}_{2}$ emission $12,886 \mathrm{~kg} \mathrm{CO}_{2} \mathrm{yr}^{-1}$ and could reduce the amount of waste generation from DBC at $43,654 \mathrm{~kg} \mathrm{yr}^{-1}$ around KKU area or $0.399 \%$ [16].

\section{Conclusions}

The survey used to assess the $\mathrm{DBC}$ waste generation rate by KKU students found a rate of 0.46 pairs person $^{-1}$ $\mathrm{d}^{-1}$. To minimize waste collection problems caused by DBC waste, DBC waste separation and simple recycling by converting DBCs to charcoal for use as a biomass fuel for electricity generation by gasification process was considered. DBC waste used directly as a combustion fuel was compared in terms of fuel quality with $\mathrm{DBC}$ that had undergone 1-h carbonization process at 650 and $900{ }^{\circ} \mathrm{C}$. The findings revealed that the DBC charcoal processed at $650{ }^{\circ} \mathrm{C}$ achieved a high-quality charcoal, increasing the calorific value by 1.8 times relative to directly burned DBC and reaching a thermal efficiency of $31 \%$. The small particles attached to the pores surface, assumed as volatile organic matter particles (9.2\% mass content of volatile matters), observed in the SEM images supported the results of the highest BET surface area and easy ignition property and highest thermal efficiency which was considered as the environmentally friendly biomass fuel due to low sulfur content to calorific value of $9.72 \times 10^{-5} \mathrm{~kg} \mathrm{MJ}^{-1}$ or only $1 / 5$ times compare to of the bituminous coal. Utilization of $650{ }^{\circ} \mathrm{C} \mathrm{DBC}$ charcoal as alternative biomass fuel resources for electricity production by gasification process in case of KKU area could reduce $0.399 \%$ of total waste generation, produce $0.0395 \%$ of total electricity consumption and reduce $\mathrm{CO}_{2}$ emission by around $12,886 \mathrm{~kg} \mathrm{CO}_{2} \mathrm{yr}^{-1}$.

\section{Acknowledgements \\ This work was supported by Rajamangala University of Technology, Isan Surin Campus.}

\section{Authors' contributions}

Supin contributed to the design and implementation of the research and the analysis of the results. The suggested experiments are advised by Pairaya, Chaiyaput and Krit. Supin wrote and Pairaya proofread the article. The author(s) read and approved the final manuscript.

Funding

This work was supported by Not applicable. 
Availability of data and materials

Not applicable.

\section{Declarations}

\section{Competing interests}

The authors declare they have no competing interests.

\section{Author details}

'Department of Environmental Engineering, Khon Kaen University, Khon Kaen 40002, Thailand. ${ }^{2}$ Research Center for Environmental and Hazardous Substance Management, Khon Kaen University, Khon Kaen 40002, Thailand. ${ }^{3}$ Center of Excellence on Hazardous Substance Management, Bangkok 10330, Thailand. ${ }^{4}$ Department of Chemical Engineering, Khon Kaen University, Khon Kaen 40002, Thailand. ${ }^{5}$ Department of Electrical Engineering, Khon Kaen University, Khon Kaen 40002, Thailand.

Received: 25 December 2020 Accepted: 29 July 2021

Published online: 07 October 2021

\section{References}

1. Luo C. China's 80 billion disposable chopsticks a burden on forests. Hong Kong: South China Morning Post; 2013.

2. Chen DY, Zhou JB, Zhang QS. Effects of heating rate on slow pyrolysis behavior, kinetic parameters and products properties of moso bamboo. Bioresour Technol 2014:169:313-9.

3. Mingjie G. Manual for bamboo charcoal production and utilization. Nanjing: East Nanjing Forestry University; 2004

4. Basu P. Biomass gasification and pyrolysis: practical design. Burlington: Academic Press; 2010

5. FAO. Using charcoal efficiently. In: Simple technologies for charcoal making. Rome: Food and Agriculture Organization; 1983.

6. Ahuja DR, Joshi V, Smith KR, Venkataraman C. Thermal performance and emission characteristics of unvented biomass-burning cookstoves: a proposed standard method for evaluation. Biomass 1987;12:247-70.

7. Mahanim SMA, Asma IW, Rafidah J, Puad E, Shaharuddin H. Production of activated carbon from industrial bamboo wastes. J Trop For Sci 2011;23: 417-24

8. Krejcie RV, Morgan DW. Determining sample size for research activities. Educ Psychol Meas 1970;30:607-10.

9. Emrich W. Handbook of charcoal making: the traditional and industrial methods. Dordrecht: Springer Science+Business Media; 1985.

10. McKendry P. Energy production from biomass (part 1): overview of biomass. Bioresour Technol 2002;83:37-46.

11. Uchimiya M, Wartelle LH, Klasson KT, Fortier CA, Lima IM. Influence of pyrolysis temperature on biochar property and function as a heavy metal sorbent in soil. J Agr Food Chem 2011;59:2501-10.

12. Speight JG. Handbook of coal analysis, Volume 166. Hoboken: Wiley; 2005.

13. Xiang YL, Cai L, Guan YW, Liu WB, He TZ, Li J. Study on the biomass-based integrated gasification combined cycle with negative $\mathrm{CO}_{2}$ emissions under different temperatures and pressures. Energy 2019;179:571-80.

14. KKU. Report on the Electricity Consumption Rate in Khon Kaen University. Khon Kaen: Khon Kaen University; 2015 [in Thai]. https://home.kku.ac.th/ta wiset/downloads/elt_report_58.pdf.

15. MOE. Power Development Plan 2018-2037: PDP2018. Bangkok: Ministry of Energy; 2018 [in Thai].

16. Ponsakkhua W, Pitaksanurat S, Rittirod T. Cost of garbage disposal of Khon Kaen University. In: The 8th National Conference on Business Management and Innovation. Khon Kaen; 2015. [in Thai] https://mba.kku.ac.th/ncbmi/ proceeding/2015/national/files/503.pdf.

\section{Publisher's Note}

Springer Nature remains neutral with regard to jurisdictional claims in published maps and institutional affiliations.

Ready to submit your research? Choose BMC and benefit from:

- fast, convenient online submission

- thorough peer review by experienced researchers in your field

- rapid publication on acceptance

- support for research data, including large and complex data types

- gold Open Access which fosters wider collaboration and increased citations

- maximum visibility for your research: over $100 \mathrm{M}$ website views per year

At BMC, research is always in progress.

Learn more biomedcentral.com/submissions 